\title{
ANALISIS PERBEDAAN PRODUKTIVITAS KERJA KARYAWAN TETAP, KONTRAK DAN PEKERJA HARIAN LEPAS (PHL) DI PDAM KOTA BENGKULU
}

\author{
Ida Anggriani, Aan Ramadhan Saputra \\ Program Studi Manajemen, Fakultas Ekonomi Universitas Dehasen Bengkulu \\ Ida_anggriani@Yahoo.com
}

\begin{abstract}
ABSTRAK
Ida Anggriani, Aan Ramadhan Saputra ; Tujuan yang ingin dicapai melalui penelitian ini adalah untuk mengetahui perbedaan produktivitas kerja antara karyawan tetap, kontrak dan Pekerja Harian Lepas (PHL) di PDAM Kota Bengkulu. Metode analisis dalam penelitian ini adalah Penganalisan data tentang perbedaan produktivitas antara karyawan tetap, kontrak dan Pekerja Harian Lepas (PHL) di PDAM Kota Bengkulu menggunakan uji anova satu arah (one-way anova), yang digunakan untuk menguji perbandingan rata-rata antara beberapa kelompok data. Untuk menganalisis datanya dalam hal ini peneliti menggunakan bantuan komputer program SPSS 19 for windows.

Berdasarkan hasil penelitian dan pembahasan menunjukkan ada perbedaan yang bermakna produktivitas kerja antara karyawan tetap, kontrak dan pekerja harian lepas di PDAM Kota Bengkulu (sig $0,002>0,05$ ). Statistik deskriptif menunjukkan bahwa rata-rata skor produktivitas kerja karyawan tetap sebesar 91,75, rata-rata produktivitas kerja karyawan kontrak sebesar 98,14 dan rata-rata produktivitas kerja pekerja harian lepas sebesar 97,53. Hasil ini menunjukkan bahwa produktivitas kerja karyawan kontrak lebih dominan dibandingkan kedua kelompok karyawan lainnya. Selanjutnya, pekerja harian lepas memiliki rata-rata produktivitas kerja tertinggi kedua, sedangkan karyawan tetap memiliki produktivitas kerja dengan nilai rata-rata terendah dibandingkan kedua kelompok lainnya.
\end{abstract}

\section{ABSTRACT}

Ida Anggriani, Aan Ramadhan Saputra; The purpose of this study was to analyze and determine the differences in work productivity between employees, contracts and freelancers at PDAM of Bengkulu City.The research method used in this research is descriptive and comparative method. Respondents were 148 employees of PDAM Bengkulu city, consisting of 68 employees, 65 contract workers and 15 freelance workers. Data were collected by distributing questionnaires to respondents, data analysis was done using one-way anova (one-way anova) test, which was used to test the average comparison between several groups of data.

The results showed that there were significant differences in work productivity between permanent employees, contract workers and freelancers at PDAM Bengkulu city (sig 0.002>0.05). Descriptive statistics show that the average work productivity score of permanent employees is 91.75, the average work productivity of contract workers is 98.14 and the average work productivity of freelance workers is 95.14. These results indicate that contract workers' productivity is more dominant than the other two groups of employees. Furthermore, freelance workers have the second highest average work productivity, while permanent employees have work productivity with the lowest average value compared to the other two groups.

\section{Key Words: Work Productivity, Employees, Contract Workers, Freelance Workers}

\section{LATAR BELAKANG}

Tenaga kerja pada setiap perusahaan memegang peranan penting karena tenaga kerja dapat meningkatkan kemampuan perusahaan untuk beroperasi secaraefektif dan efisien dalam rangka pencapaian tujuan-tujuan perusahaan. Olehkarena itu setiap pimpinan perlu membina hubungan yang baik dengankaryawannya dalam arti pimpinan memperhatikan apa yang baik menjadikebutuhan dan keinginan karyawan, seperti perhatian terhadap hal-hal yang dapatmendorong para karyawan bekerja secara penuh dengan produktivitas kerja yang tinggi.

Sumber keunggulan bersaing bisa didasarkan pada produktivitas kerja. Menurut Famade dkk dalam Priscilia (2017:1) bahwa produktivitas akan timbul ketika terdapat kenaikan output seiring dengan penurunan input atau dengan output yang sama tetapi dengan input yang menurun. Perbaikan produktivitas bisa dilakukan oleh perusahaan melalui dua sisi yaitu: individual dan institusional. Peningkatan produktivitas dari sisi individual yaitu melalui peningkatan kemampuan karyawan dan peningkatan produktivitas secara institusional berhubungan dengan sinergi kerja antar bagian dalam 
perusahaan, teknologi penunjang dalam perusahaan, dan berbagai fasilitas lain yang mampu meningkatkan efisiensi dan efektifitas pekerjaan. Pendapat tersebut didukung oleh Budiartha dkk (2015:2) bahwa keunggulan bersaing bisa dicapai oleh perusahaan jika perusahaan memiliki sumberdaya yang kompetitif khususnya sumberdaya manusia.

Upaya untuk meningkatkan produktivitas juga dilakukan dengan pemberdayaan karyawan, sebagaimana pendapat Kahreh dkk dalam Priscilia (2017:1). Pendapatnya mengungkapkan bahwa pemberdayaan karyawan akan mampu memfasilitasi kreasi sehingga tercipta integrasi lingkungan yang berkualitas dengan mampu menghasilkan produk dan layanan yang superior. Pendapat yang relatif sama mengenai upaya untuk meningkatkan produktivitas juga dinyatakan oleh Budiartha dkk (2015:2), bahwa peningkatan produktivitas perusahaan bisa dicapai ketika perusahaan mampu melakukan pengelolaan dengan baik sumberdaya manusia yang demikian karena sumberdaya manusia adalah faktor manusia sebagai pelaku utama dalam setiap kegiatan operasional suatu perusahaan, semakin baik kemampuan SDM yang dimiliki maka akan semakin baik hasil yang dicapai, demikian pula sebaliknya.

Berbagai kajian teori sepakat bahwa perusahaan harus memiliki daya saing, dan daya saing bisa dicapai ketika perusahaan mampu meningkatkan produktivitas. Produktivitas perusahaan bisa dicapai melalui produktivitas individu (karyawan) dan produktivitas institusional. Meskipun demikian, upaya untuk mempertahankan dan meningkatkan produktivitas juga bukan hal yang mudah. Salah satunya dialami di PDAM Kota Bengkulu, perusahaan ini bergerak di bidang pengolahan dan pendistribusian air kepada masyarakat Kota Bengkulu. Sampai saat ini PDAM Kota Bengkulu memiliki 216 karyawan, terdiri dari 136 karyawan tetap, 65 karyawan kontrak dan15 pekerjaan harian lepas (PHL).

Masing-masing karyawan tersebut mendapatkan gaji pokok, tunjangan, insentif, jaminan kesehatan yang berbeda-beda. Misalnya untuk gaji pokok pada karyawan tetap untuk masa kerja nol mengikuti PNS sebesar Rp 2.456.700 per bulan, sedangkan untuk karyawan kontrak dan PHL mengikuti UMP sebesar Rp. 1.888.741. Dari segi tunjangan dan insentif, karyawan tetap dan kontrak mendapatkan tunjangan perumahan dan tunjangan anak masuk sekolah, sedangkan karyawan PHL tidak menerima. Kemudian dari segi jaminan kesehatan, karyawan tetap yang memiliki jabatan mendapatkan jaminan kesehatan kelas satu, sedangkan karyawan tetap non jabatan dan karyawan kontrak mendapatkan jaminan kesehatan kelas dua. Untuk karyawan PHL tidak mendapatkan jaminan kesehatan dari perusahaan. Adanya perbedaan perlakuan antara karyawan sedikit banyak dapat menyebabkan ketidakpuasan karyawan dan dapat menurunkan produktivitas kerja.

Terkait dengan permasalahan produktivitas kerja, masih banyak karyawan kurang produktif, seperti ditunjukkan dengan perilaku karyawan yang lebih mementingkan absensi dari pada penyelesaian pekerjaan, Karyawan pada kelompok ini datang dan pulang tepat waktu, namun kegiatannya di perusahaan lebih banyak dihabiskan di kantin, membicarakan hal-hal yang tidak penting atau mengobrol sana sini dan hal-hal yang tidak produktif lainnya.

\section{LANDASAN TEORI Produktivitas Kerja}

Produktivitas kerja merupakan suatu hal yang penting bagi suatu organisasi baik itu yang bergerak di bidang jasa maupun produksi barang. Konsep dasar dari produktivitas kerja terdiri dari daya guna (efisiensi) dan hasil guna (efektivitas). Menurut Umar (2010:99) bahwa produktivitas adalah sik apmental yang selalu berpandangan bahwa mutu kehidupan hari ini harus lebih baik dari hari kemarin dan esok hari harus lebih baik dari hari ini. Sedangkan Sedarmayanti (2011:57) menyatakan bahwa produktivitas adalah bagaimana menghasilkan atau meningkatkan hasil barang dan jasa setinggi mungkin dengan memanfaatkan sumber daya manusia secara efisien. Oleh karena itu produktivitas sering diartikan sebagai rasio antara keluaran dan masukan dalam satuan tertentu. Produktivitas merupakan perbandingan antara keluaran dan masukan serta mengutamakan cara pemanfaatan baik terhadap sumber-sumber dalam memproduksi suatu barang atau jasa (Hasibuan, 2015: 128).

Seorang karyawan dinilai produktif apabila menghasilkan output yang lebih besar dari karyawan lainnya untuk satuan waktu yang sama. Dan dapat juga dikatakan bahwa karyawan menunjukkan tingkat produktivitas yang ditentukan dalam satuan waktu yang lebih singkat. Dari uraian di atas dapat disimpulkan bahwa produktivitas adalah kemampuan karyawan dalam mengelola dan memanfaatkan sumber daya yang dimiliki untuk memperoleh keluaran atau hasil yang optimal dalam rangka pelaksanaan tugas yang telah dibebankan kepadanya serta pencapaian hasil kerja yang telah ditentukan. 


\section{Faktor yang Mempengaruhi Produktivitas Kerja}

Menurut Sinungan (2013:74) ada enam faktor yang mempengaruhi produktivitas kerja seseorang yaitu :

1. Kuantitas, kuantitas adalah kemampuan seseorang untuk menciptakan suatu barang atau jasa yang dapat berguna bagi dirinya sendiri maupun orang lain.

2. Tingkat keahlian (skill) yang dimiliki seseorang, semakin tinggi tingkat keahlian yang dimiliki seseorang, maka akan semakin tinggi pula produktivitasnya.

3. Latar Belakang dan Pendidikan, latar belakang dan pendidikan seseorang sangat mempengaruhi produktivitas kerjanya, semakin baik latar belakang dan pendidikan seseorang maka akan semakin tinggi pula produktivitas kerjanya.

4. Kemampuan Sikap, termasuk kemampuan dan sikap seseorang dalam menangani dan memecahkan persoalan yang dihadapi.

5. Minat, seseorang dapat membuat ia menjadi terpromosi untuk bekerja sebaik mungkin, karena sesuatu yang dilakukan sesuai dengan minat dan keinginannya.

6. Struktur Pekerjaan. Keahlian, umur dan jenis kelamin serta angkatan kerja. Seseorang akan bekerja lebih baik dan lebih bersemangat bila ia memperoleh jabatan menuntut tanggung jawab yang lebih tinggi. Jenis kelamin serta umur yang berada dalam usia kerja dapat mempengaruhi produktivitas kerja seseorang karena semakin jauh umur seseorang dari usia kerja, maka produktivitas kerjanya juga akan mengalami penurunan.

Produktivitas kerja karyawan berhubungan dengan berbagai factor baik yang berhubungan dengan karyawan itu sendiri, maupun faktor lain yang saling berhubungan, sehingga perlu diadakan penyederhanaan. Menurut Ravianto (2010:15) menggolongkan faktor-faktor tersebut sebagai berikut:

1. Tingkat pendidikan

2. Motivasi kerja

3. Disiplin kerja

4. Sikap dan etika kerja

5. Gizi dan kesehatan

6. Teknologi

7. Manajemen

8. Kesempatan untuk berprestasi

9. Lingkungan dan iklim kerja

Timpe (2012:42) menyatakan bahwa walaupun tidak ada dua individu yang sama, mungkin dapat dikembangkan suatu wadah yang mencakup ciri-ciri umum karyawan yang produktif, yaitu :

1. Lebih dari memenuhi kualifikasi pekerjaan.

Kualifikasi pekerjaan dianggap hal yang mendasar karena produktifitas tinggi tidak mungkin tanpa kualifikasi yang benar. Pengamatan yang khas adalah:

a. Cerdas dan dapat belajar dengan cepat.

b. Kompeten secara profesional atau teknis, selalumemperdalam pengetahuan dalam bidangnya.

c. Memahami pekerjaan.

d. Selalu mencari perbaikan, tetapi tahu kapan harus berhenti menyempurnakan.

e. Dianggap bernilai oleh pengawasnya.

2. Semangat tinggi.

Semangat disebut sebagai faktor kritis karyawan yang terdorong berada di jalan ke produktivitas tinggi. Pengamatan yang khas adalah:

a. Tekun, bekerja secara produktif pada suatu tugas sampai selesai dengan baik dan dapat menyelesaikan pekerjaan walaupun mendapat rintangan.

b. Mempunyai kemauan keras untuk bekerja, selalu sibuk.

c. Bekerja efektif dengan atau tanpa pengawasan.

d. Menyukai tantangan; ingin menguji kemampuannya, menyukai pencarian pemecahan masalah.

e. Selalu tepat waktu dan ingin menepati waktu.

3. Mempunyai orientasi pekerjaan positif.

Sikap seseorang terhadap tugas pekerjaan sangat mempengaruhi kinerjanya. Sikap positif dikatakan sebagai faktor utama dalam produktivitas pegawai. Pengamatan yang khas adalah:

a. Menyukai pekerjaannya dan membanggakannya; ia memandangnya sebagai sumber utama pemuasan kebutuhannya.

b. Menetapkan standar yang tinggi.

c. Mempunyai kebiasaan kerja yang baik.

d. Selalu terlibat dalam pekerjaannya. 
e. Luwes dan dapat menyesuaikan diri dengan perubahan.

4. Dewasa.

Kedewasaan adalah suatu atribut pribadi yang dinilai penting oleh peserta studi. Pegawai yang dewasa memperlihatkan kinerja yang konsisten dan hanya memerlukan pengawasan minimal. Pengamatan yang khas adalah:

a. Mempunyai rasa tanggung jawab yang kuat.

b. Mengetahui kekuatan/kelemahan sendiri.

c. Hidup dalam dunia "nyata" bergaul secara efektif dengan lingkungan.

d. Dapat berkinerja efektif di bawah tekanan.

e. Dapat belajar dari pengalaman.

5. Dapat bergaul dengan efektif.

Kemampuan untuk memantapkan hubungan antar pribadi yang positif adalah aset yang sangat meningkatkan produktivitas. Pengamatan yang khas adalah:

a. Memperagakan kecerdasan sosial.

b. Pribadi yang menyenangkan; diterima dan bergaul efektif baik dengan atasan maupun teman sejawat.

c. Berkomunikasi dengan efektif; jelas dan cermat, terbuka terhadap saran pendengar yang baik.

d. Bekerja produktif dalam rangka upaya tim; dapat bekerja sama, berbagi gagasan; membantu teman sejawat.

e. Memperagakan sikap positif dan antusiasme.

Adanya ciri diri di atas, memudahkan untuk mengamati dan mengukur produktivitas kerja karyawan sehingga dapat diketahui sejauh mana produktivitas yang dicapai oleh karyawan tersebut. Selain itu pengukuran produktivitas juga dapat digunakan sebagai pedoman bagi para atasan untuk meningkatkan produktivitas kerja sesuai dengan apa yang diharapkan oleh organisasi.

\section{Kerangka Penelitian}

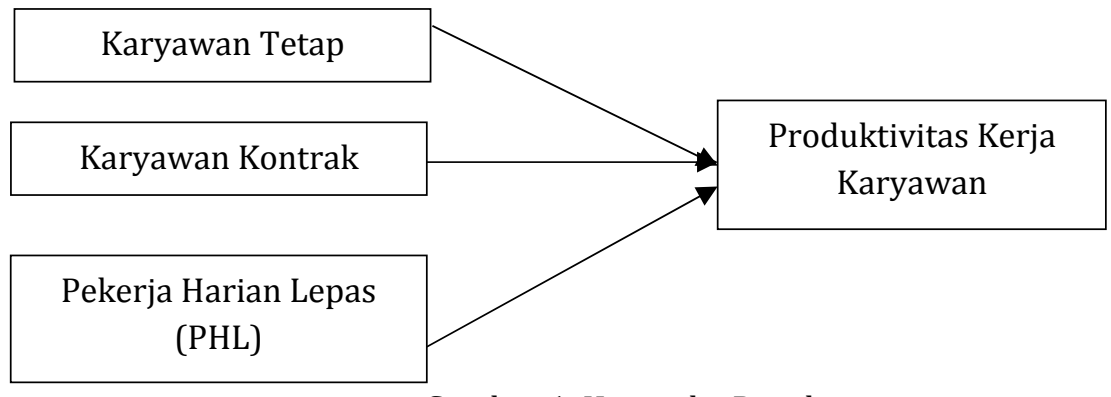

Gambar 1. Kerangka Penelitian

\section{Hipotesis}

Hipotesis penelitian ini sebagai berikut:

Ha: Ada perbedaan produktivitas antara karyawan tetap, kontrak dan Pekerja Harian Lepas (PHL) di PDAM Kota Bengkulu.

Ho: Tidak ada perbedaan produktivitas antara karyawan tetap, kontrak dan Pekerja Harian Lepas (PHL) di PDAM Kota Bengkulu.

\section{METODE PENELITIAN}

\section{Jenis Penelitian}

Metode penelitian yang digunakan dalam penelitian ini adalah metode deskriptif dan komparatif. Menurut Sugiyono (2014:54), penelitian komparatif adalah penelitian yang membandingkan keadaan satu variabel atau lebih pada dua atau lebih sampel yang berbeda, atau dua waktu yang berbeda. Adapun penerapan penelitian komparatif pada penelitian ini digunakan untuk mengetahui perbedaan produktivitas antara karyawan tetap, kontrak dan Pekerja Harian Lepas (PHL) di PDAM Kota Bengkulu.

\section{Definisi Operasional}

Definisi operasional dan pengukuran variabel penelitian ini adalah sebagai berikut:

1. Produktivitas kerja adalah kemampuan karyawan PDAM Kota Bengkulu dalam mengelola dan memanfaatkan sumber daya yang dimiliki untuk memperoleh keluaran atau hasil yang optimal dalam 
rangka pelaksanaan tugas yang telah dibebankan kepadanya serta pencapaian hasil kerja yang telah ditentukan. Produktivitas diukur berdasarkan indikator yang dijelaskan Timpe (2012:42):

a. Lebih dari memenuhi kualifikasi pekerjaan

b. Semangat tinggi

c. Mempunyai orientasi pekerjaan positif

d. Dewasa

e. Dapat bergaul dengan efektif

2. Karyawan tetap adalah karyawan yang telah memiliki kontrak ataupun perjanjian kerja dengan PDAM Kota Bengkulu dalam jangka waktu yang tidak ditetapkan (permanent).

3. Karyawan kontrak adalah karyawan yang bekerja pada PDAM Kota Bengkulu yang melakukan pekerjaan yang bersifat sementara dan dapat dilakukan untuk jangka waktu paling lama dua tahun dan dapat diperpanjang untuk satu kali paling lama satu tahun.

4. Pekerja harian lepas adalahkaryawan yang bekerja pada PDAM Kota Bengkulu dimana waktu dari pekerjaan mereka tidak ditentukan secara pasti. Karyawan ini biasanya dapat diberhentikan sewaktuwaktu ketika perusahaan sudah tidak membutuhkan tenaga tambahan lagi.

\section{Metode Pengambilan Sampel}

Populasi dalam penelitian ini adalah karyawan PDAM Kota Bengkulu sebanyak 216 karyawan, terdiri dari 136 karyawan tetap, 65 karyawan kontrak dan 15 Pekerja Harian Lepas (PHL). Menurut Arikunto (2012:118), sampel adalah sebagian objek penelitian yang diambil dan dianggap dapat mewakili semua populasi. Dalam hal ini apabila subjek kurang dari 100, lebih baik diambil semua sehingga penelitiannya merupakan penelitian populasi, selanjutnya jika penelitian itu lebih dari 100, maka diambil $10-25 \%$ atau lebih.

Berdasarkan pendapat di atas maka dalam penelitian ini penelitian mengambil sampel maksimum sebanyak 25\% dari jumlah populasi dikarenakan populasi lebih dari 100. Jadi jumlah sampel dalam penelitian ini adalah 148 karyawan. Teknik penentuan sampel untuk kelompok karyawan tetap dilakukan secara random sedangkan karyawan kontrak dan PHL dengan sensus. Untuk lebih jelasnya distribusi sampel penelitian dapat dilihat pada tabel berikut:

Tabel 1. Jumlah Sampel

\begin{tabular}{|c|l|c|c|c|}
\hline No & \multicolumn{1}{|c|}{ Jenis Tenaga Kerja } & Populasi & Perhitungan & $\begin{array}{c}\text { Sampel } \\
\text { (Pembulatan) }\end{array}$ \\
\hline 1 & Karyawan tetap & 136 & $136 \times 25 \%$ & 68 \\
\hline 2 & Karyawan kontrak & 65 & - & 65 \\
\hline 3 & Pekerja Harian Lepas (PHL) & 15 & - & 15 \\
\hline \multicolumn{2}{r}{ Jumlah } & 216 & & 148 \\
\hline
\end{tabular}

\section{Metode Pengumpulan Data}

Metode pengumpulan data dalam penelitian ini dilakukan dengan kuesioner. Pengukuran variabel yang diperlukan dalam penelitian ini adalah skala likert, dimana responden menyatakan tingkat setuju atau tidak setuju mengenai beberapa pernyataan tentang perilaku, objek, orang, atau kejadian. dengan menggunakan skala likert. Dalam melakukan penelitian terhadap variabel-variabel yang akan diuji, pada setiap jawaban akan diberikan skor (Sugiyono, 2014:86). Pengukuran dengan Skala Likert ini dilakukan dengan pembagian :

Tabel 2. Pengukuran dengan Skala Likert

\begin{tabular}{|c|c|}
\hline Jawaban & Skor/bobot \\
\hline Sangat Tidak Setuju (STS) & 1 \\
\hline Tidak Setuju (TS) & 2 \\
\hline Cukup Setuju (CS) & 3 \\
\hline Setuju (S) & 4 \\
\hline Sangat Setuju (SS) & 5 \\
\hline
\end{tabular}

Sumber: Sugiyono (2014:86) 


\section{Metode Analisis}

Penganalisan data tentang perbedaan produktivitas antara karyawan tetap, kontrak dan Pekerja Harian Lepas (PHL) di PDAM Kota Bengkulu menggunakan uji anova satu arah (one-way anova), yang digunakan untuk menguji perbandingan rata-rata antara beberapa kelompok data. Untuk menganalisis datanya dalam hal ini peneliti menggunakan bantuan komputer program SPSS 19 for windows. Sebelum dilakukan analisis uji one way anova, maka perlu dilakukan uji normalitas sebaran dan uji homogenitas.

1. Uji normalitas

Uji normalitas data dilakukan dengan tujuan untuk mengetahui kenormalan distribusi sebaran skor variabel. Untuk mengetahui normalitas dapat digunakan skor signifikansi yang ada pada hasil penghitungan Kolmogorov-smirnov. Bila angka signifikansi lebih besar atau sama dengan 0,05, maka terdistribusi normal, tetapi apabila kurang, maka data tidak terdistribusi normal (Azwar, 2014:107).

2. Uji Homogenitas

Menurut Hakim (2012:196) uji homogenitas digunakan untuk menguji apakah dua (atau lebih) populasi adalah homogen (sama) sehubungan dengan suatu distribusi sifat tertentu. Uji One-Way ANOVA dapat dilakukan jika data memiliki varians yang sama. Varians data dapat diuji dengan menggunakan Levene test. Bila nilai sig $>0,05$ maka data diasumsikan memiliki varians yang sama. Bila nilai sig $<0,05$ maka data diasumsikan memiliki varians yang tidak sama.

3. Pengujian Hipotesis

Pengujian hipotesis dilakukan dengan alat uji statistik yaitu analisis varians. Menurut Hakim (2012:208), analisis varians merupakan uji hipotesis mean lebih dari dua populasi. Analisis varian yang digunakan adalah One-way ANOVA (Anova Satu Arah). One-way ANOVA biasa dikenal dengan nama one factor completely randomized design of ANOVA adalah uji hipotesis beda mean atau lebih dari dua populasi jika setiap anggota yang terlibat dalam pengukuran bebas untuk terletak di populasi mana saja, artinya tidak ada kesenjangan untuk mengatur letak suatu anggota dalam suatu populasi tertentu (sehingga disebut completely randomized).

Menurut Hakim (2012:208), uji anova satu arah (one way ANOVA) adalah jenis uji statistika parametrik yang bertujuan untuk mengetahui apakah terdapat perbedaan rata-rata antara lebih dari dua group sampel. Yang dimaksud satu arah adalah sumber keragaman yang dianalisis hanya berlangsung satu arah yaitu antar perlakuan (Between Group).

Hipotesis yang digunakan adalah:

Ho : Tidak ada perbedaan produktivitas kerja antara karyawan tetap, kontrak dan Pekerja Harian Lepas (PHL) di PDAM Kota Bengkulu

Ha : Ada perbedaan produktivitas kerjaantara karyawan tetap, kontrak dan Pekerja Harian Lepas (PHL) di PDAM Kota Bengkulu

Kriteria pengujian hipotesis:

a. Bila nilai sig $>0,05$ maka Ho diterima dan Ha ditolak, artinya tidak ada perbedaan produktivitas kerja antara karyawan tetap, kontrak dan Pekerja Harian Lepas (PHL) di PDAM Kota Bengkulu.

b. Bila nilai sig $<0,05$ maka Ho ditolak dan Ha diterima, artinya ada perbedaan produktivitas kerja antara karyawan tetap, kontrak dan Pekerja Harian Lepas (PHL) di PDAM Kota Bengkulu

\section{HASIL PENELITIAN DAN PEMBAHASAN}

Untuk melakukan uji One-way Anova, harus dipenuhi beberapa asumsi, yaitu data masing-masing kelompok terdistribusi normal dan varian antar kelompok harus homogen.

\section{Uji Normalitas Data}

Untuk mengetahui normalitas digunakan skor signifikansi yang ada pada hasil penghitungan Kolmogorov-smirnov. Bila angka signifikansi lebih besar atau sama dengan 0,05, maka terdistribusi normal, tetapi apabila kurang, maka data tidak terdistribusi normal. Berikut hasil pengujian normalitas dengan uji Kolmogorov-smirnov : 
Tabel 3. Normalitas Data Produktivitas Kerja Karyawan Tetap One-Sample Kolmogorov-Smirnov Test

\begin{tabular}{|ll|r|}
\hline & & $\begin{array}{c}\text { Produktivitas Kerja } \\
\text { Karyawan Tetap }\end{array}$ \\
\hline $\mathrm{N}$ & & 68 \\
Normal Parameters & Mean & 91.7500 \\
& Std. Deviation & 12.26495 \\
Most Extreme Differences & Absolute & .151 \\
& Positive & .092 \\
& Negative & -.151 \\
Kolmogorov-Smirnov Z & & 1.243 \\
Asymp. Sig. (2-tailed) & & .091 \\
\hline
\end{tabular}

a. Test distribution is Normal.

b. Calculated from data.

Sumber: Hasil penelitian, 2018 (data diolah)

Berdasarkan Tabel 3 di atas, hasil uji Kolmogorov-Smirnov untuk variabel produktivitas kerja karyawan tetap memberikan nilai sebesar 1,243 dengan probabilitas signifikansi sebesar 0,091 dan nilainya lebih besar dari 0,05. Jadi dapat disimpulkan bahwa sebaran skor variabel produktivitas kerja karyawan tetap berdistribusi normal.

Tabel 4. Normalitas Data Produktivitas Kerja Karyawan Kontrak One-Sample Kolmogorov-Smirnov Test

\begin{tabular}{|c|c|c|}
\hline & & Produktivitas Kerja Karyawan Kontrak \\
\hline $\mathrm{N}$ & & 65 \\
\hline \multirow[t]{2}{*}{ Normal Parameters ${ }^{\mathrm{a}, \mathrm{b}}$} & Mean & 98.1385 \\
\hline & Std. Deviation & 9.16665 \\
\hline \multirow[t]{3}{*}{ Most Extreme Differences } & Absolute & .196 \\
\hline & Positive & .143 \\
\hline & Negative & -.196 \\
\hline Kolmogorov-Smirnov Z & & 1.179 \\
\hline Asymp. Sig. (2-tailed) & & .814 \\
\hline
\end{tabular}

a. Test distribution is Normal.

b. Calculated from data.

Sumber: Hasil penelitian, 2018 (data diolah)

Berdasarkan Tabel 4 di atas, hasil uji Kolmogorov-Smirnov untuk variabel produktivitas kerja karyawan kontrak memberikan nilai sebesar 1,179 dengan probabilitas signifikansi sebesar 0,814 dan nilainya lebih besar dari 0,05. Jadi dapat disimpulkan bahwa sebaran skor variabel produktivitas kerja karyawan kontrak berdistribusi normal.

Tabel 5. Normalitas Data Produktivitas Kerja Karyawan PHL

One-Sample Kolmogorov-Smirnov Test

\begin{tabular}{|c|c|c|}
\hline & & $\begin{array}{c}\text { Produktivitas Kerja } \\
\text { Karyawan PHL }\end{array}$ \\
\hline $\mathrm{N}$ & & 15 \\
\hline \multirow{2}{*}{ Normal Parameters ${ }^{\mathrm{a}, \mathrm{b}}$} & Mean & 97.5333 \\
\hline & Std. Deviation & 3.27036 \\
\hline \multirow[t]{3}{*}{ Most Extreme Differences } & Absolute & .120 \\
\hline & Positive & .117 \\
\hline & Negative & -.120 \\
\hline Kolmogorov-Smirnov Z & & .463 \\
\hline Asymp. Sig. (2-tailed) & & .983 \\
\hline
\end{tabular}

a. Test distribution is Normal.

b. Calculated from data.

Sumber: Hasil penelitian, 2018 (data diolah) 
Berdasarkan Tabel 5 di atas, hasil uji Kolmogorov-Smirnov untuk variabel produktivitas kerja karyawan PHL memberikan nilai sebesar 0,463 dengan probabilitas signifikansi sebesar 0,983 dan nilainya lebih besar dari 0,05. Jadi dapat disimpulkan bahwa sebaran skor variabel produktivitas kerja karyawan PHL berdistribusi normal.

\section{Uji One-way Anova}

Berikut ini adalah hasil rata-rata skor produktivitas kerja antara karyawan tetap, kontrak dan PHL di Perusahaan Daerah Air Minum (PDAM) Kota Bengkulu :

Tabel 6. Statistic Descriptives

\begin{tabular}{|l|r|r|r|r|}
\hline & & & & \\
& $\mathrm{N}$ & Mean & Std. Deviation & Std. Error \\
\hline Tetap & 68 & 91.75 & 12.265 & 1.487 \\
Kontrak & 65 & 98.14 & 9.167 & 1.137 \\
PHL & 15 & 97.53 & 3.270 & .844 \\
Total & 148 & 95.14 & 10.772 & .885 \\
\hline
\end{tabular}

Sumber: Hasil penelitian, 2018 (data diolah)

Berdasarkan Tabel 6 dapat dilihat bahwa responden dengan status karyawan tetap rata-rata skor produktivitas kerja sebesar 91,75 dan standar deviasi sebesar 12,265. Standar deviasi memiliki makna bahwa jarak setiap titikdata karyawan tetap dengan nilai rata-rata produktivitasnya sebesar 12,265. Karyawan dengan status kontrak, rata-rata skor produktivitas kerja sebesar 98,14dengan standar deviasi sebesar 9,167. Artinya, jarak setiap titik data karyawan kontrak dengan nilai rata-rata produktivitasnya sebesar 9,167. Karyawan dengan status PHL rata-rata skor produktivitas sebesar97,53 dengan standar deviasi sebesar 3,270. Artinya, jarak setiap titik data karyawan PHL dengan nilai rata-rata produktivitasnya sebesar 3,270.

Berdasarkan nilai skor produktivitas dapat diketahui bahwa karyawan kontrak miliki skor tertinggi dibandingkan dua kelompok karyawan lainnya. Kemudian tertinggi kedua adalah produktivitas kerja Pekerja Harian Lepas, sedangkan produktivitas kerja terendah antara ketiga kelompok karyawan adalah karyawan tetap.Hasil ini belum terlihat perbedaan produktivitas kerja dari masing-masing kelompok. Untuk melihat apakah perbedaan ini memang nyata secara statistik maka harus dilihat pada tabel Anova. Namun sebelum melanjutkan uji, maka dilakukan terlebih dahulu prasyarat bahwa asumsi Anova bahwa varians data harus sama sama.

Tabel 7. Test of Homogeneity of Variances

\begin{tabular}{|c|c|c|c|}
\hline Levene Statistic & df1 & df2 & Sig. \\
\hline 16.260 & 2 & 145 & .357 \\
\hline
\end{tabular}

Sumber: Hasil penelitian, 2018 (data diolah)

Berdasarkan pengujian dengan menggunakanLevene testdiketahui bahwa signifikansi $(0,357)>0,05$ maka data diasumsikan memiliki varians yang sama, sehingga uji Anova valid untuk menguji hubungan ini. Selanjutnya untuk melihat apakah ada perbedaan produktivitas kerja dari ketiga kelompok status karyawan tersebut dapat dilihat pada tabel 8. Anova berikut :

Tabel 8. One-way Anova

\begin{tabular}{|l|r|r|r|c|r|}
\hline & Sum of Squares & \multicolumn{1}{c|}{ df } & Mean Square & F & Sig. \\
\hline Between Groups & 1451.783 & 2 & 725.892 & 6.744 & .002 \\
Within Groups & 15606.237 & 145 & 107.629 & & \\
Total & 17058.020 & 147 & & & \\
\hline
\end{tabular}

Sumber: Hasil penelitian, 2018 (data diolah)

Berdasarkan Tabel 8. One-way Anova, diperoleh nilai signifikansi sebesar 0,002<0,05 maka dapat disimpulkan bahwa Ho ditolak dan Ha diterima. Artinya,ada perbedaan yang bermakna produktivitas kerja antara karyawan tetap, kontrak dan Pekerja Harian Lepas (PHL) di PDAM Kota Bengkulu. 
Dari hasil penelitian tersebut di atas menunjukkan bahwa ada perbedaan yang bermakna produktivitas kerja antara karyawan tetap, kontrak dan Pekerja Harian Lepas (PHL) di PDAM Kota Bengkulu. Statistik deskriptif menunjukkan bahwa karyawan dengan status tetap rata-rata skor produktivitas kerja sebesar 91,75, karyawan dengan status kontrak rata-rata skor produktivitas kerja sebesar 98,14 dan karyawan dengan status PHL rata-rata skor produktivitas sebesar 97,53. Skor rata-rata produktivitas kerja yang paling dominan adalah karyawan kontrak, kelompok karyawan ini memiliki skor tertinggi dibandingkan dua kelompok karyawan lainnya. Kemudian produktivitas kerja tertinggi kedua adalah Pekerja Harian Lepas, sedangkan produktivitas kerja terendah antara kedua kelompok karyawan adalah karyawan tetap.

Pentingnya produktivitas kerja karyawan dalam menentukan tercapai atau tidaknya tujuan PDAM Kota Bengkulu harus dilakukan dengan berbagai cara. Produktivitas kerja karyawan kontrak dan PHL lebih tinggi dibandingkan karyawan tetap, diduga karena kedua karyawan pada kelompok ini dalam setiap pelaksaan tugas atau kerja harus selalu berhati-hati, sebab resiko diberhentikan lebih besar jika melakukan kesalahan dibandingkan dengan karyawan tetap. Oleh sebab itu, perlu diterapkan evaluasi kerja yang transparan kepada seluruh kelompok karyawan. Evaluasi terhadap produktivitas kerja harus sejak awal dipahami oleh semua pihak dan diterapkan secara konsisten. Evaluasi dimaksudkan untuk mengukur dan mengetahui hasil kerja karyawan dengan tanpa memandang status. Dengan penilaian yang objektif dan fair, tentu akan memberikan penghargaan dan menghadirkan kepuasan kerja bagi karyawan yang pada akhirnya akan memberikan pengaruh pada produktivitas kerjanya. Karyawan tetap di PDAM Kota bengkulu dalam hal bekerja biasa menggunakan fasilitas pendukung tanpa mempunyai beban untuk diberhentikan karena pemberhentian karyawan tetap memerlukan proses dan berbagai pertimbangan.

\section{KESIMPULAN}

Berdasarkan hasil penelitian dan pembahasan yang telah dilakukan sebelumnya, maka dapat disimpulkan bahwa ada perbedaan yang bermakna produktivitas kerja antara karyawan tetap, kontrak dan pekerja harian lepas di PDAM Kota Bengkulu (sig 0,002>0,05). Statistik deskriptif menunjukkan bahwa rata-rata skor produktivitas kerja karyawan tetap sebesar 91,75, rata-rata produktivitas kerja karyawan kontrak sebesar 98,14 dan rata-rata produktivitas kerja pekerja harian lepas sebesar 97,53. Hasil ini menunjukkan bahwa produktivitas kerja karyawan kontrak lebih dominan dibandingkan kedua kelompok karyawan lainnya. Selanjutnya, pekerja harian lepas memiliki rata-rata produktivitas kerja tertinggi kedua, sedangkan karyawan tetap memiliki produktivitas kerja dengan nilai rata-rata terendah dibandingkan kedua kelompok lainnya.

\section{SARAN}

Berdasarkan pada kesimpulan hasil penelitian yang menunjukkan adanya perbedaan produktivitas kerja karyawan tetap, kontrak dan pekerja harian lepas di PDAM Kota Bengkulu. Oleh sebab itu, manajemen PDAM Kota Bengkulu dapat menerapkan evaluasi kerja yang transparan kepada seluruh kelompok karyawan. Evaluasi harus sejak awal dipahami oleh semua pihak dan diterapkan secara konsisten. Evaluasi dimaksudkan untuk mengukur dan mengetahui hasil kerja karyawan dengan tanpa memandang status. Dengan penilaian yang objektif dan fair, tentu akan memberikan penghargaan dan menghadirkan kepuasan kerja bagi karyawan yang pada akhirnya akan memberikan pengaruh pada produktivitas kerjanya.

\section{DAFTAR PUSTAKA}

Arikunto, S. 2012. Prosedur Penelitian Suatu Pendekatan Praktik. Jakarta: Rineka Cipta.

Azwar, S. 2014. Metode Penelitian.Yogyakarta: Pustaka Pelajar

Budiartha, I.G.N., Bagia, I.W., \& Suwendra, I.W. 2015. Pengaruh Pelatihan dan Motivasi terhadap Produktivitas Kerja Karyawan. e-Journal Bisma Universitas Pendidikan Ganesha Jurusan Manajemen, Vol. 3, Hal. 1-10.

Hakim, A. 2012. Statistika Desktiptif, Yogyakarta: Ekonisia

Hasibuan, M. 2015. Organisasi dan Motivasi Dasar Peningkatan Produktivitas. Jakarta: Bumi Aksara.

Priscilia, 2017. Analisis Produktivitas Kerja pada PT. Berkat Anugerah Raya, Jurnal Manajemen Bisnis Agora Vol. 5, No. 1.

Ravianto J, 2010.Produktivitas dan Manusia Indonesia, Jakarta: SIUP

Sedarmayanti, 2011.Sumber Daya Manusia dan Produktivitas kerja, Bandung: Ilham Jaya.

Sugiyono. 2014. Metode Penelitian Pendidikan Pendekatan Kuantitatif, kualitatif, dan R\&D. Bandung: Alfabeta.

Sinungan, M. 2013. Produktivitas : Apa dan Bagaimana. Jakarta: Bumi Aksara 
Timpe, D.A. 2012. Sari Manajemen Sumber Daya Manusia: Produktivitas Kerja. Ahli Bahasa: Dimas Samudra. Jakarta: Gramedia Pustaka Utama

Umar, H. 2010. Riset Sumber Daya Manusia Dalam Organisasi. Jakarta: Gramedia Pustaka Utama 